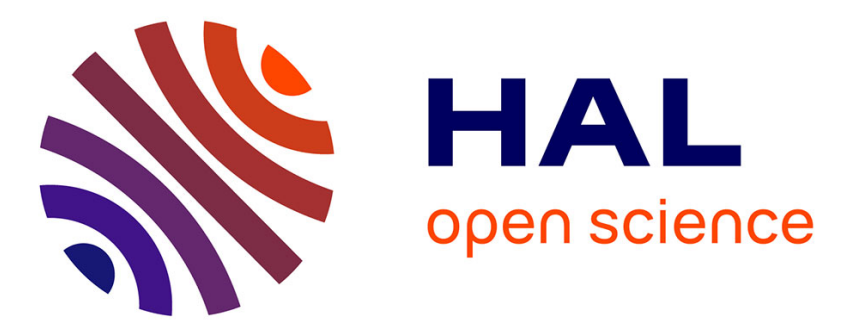

\title{
Effects of docosahexaenoic acid on some megakaryocytic cell gene expression of some enzymes controlling prostanoid synthesis.
}

Nicolas Guillot, Cyrille Debard, Catherine Calzada, Hubert Vidal, Michel Lagarde, Evelyne Véricel

\section{To cite this version:}

Nicolas Guillot, Cyrille Debard, Catherine Calzada, Hubert Vidal, Michel Lagarde, et al.. Effects of docosahexaenoic acid on some megakaryocytic cell gene expression of some enzymes controlling prostanoid synthesis.. Biochemical and Biophysical Research Communications, 2008, 372 (4), pp.9248. 10.1016/j.bbrc.2008.05.155 . inserm-00290467

\section{HAL Id: inserm-00290467 https://www.hal.inserm.fr/inserm-00290467}

Submitted on 25 Jun 2008

HAL is a multi-disciplinary open access archive for the deposit and dissemination of scientific research documents, whether they are published or not. The documents may come from teaching and research institutions in France or abroad, or from public or private research centers.
L'archive ouverte pluridisciplinaire HAL, est destinée au dépôt et à la diffusion de documents scientifiques de niveau recherche, publiés ou non, émanant des établissements d'enseignement et de recherche français ou étrangers, des laboratoires publics ou privés. 
Effects of docosahexaenoic acid on some megakaryocytic cell gene expression of some enzymes controlling prostanoid synthesis

Nicolas GUILLOT, Cyrille DEBARD, Catherine CALZADA, Hubert VIDAL, Michel LAGARDE and Evelyne VERICEL*

Université de Lyon, INSERM, U870, INSA-Lyon, (RMND- IMBL), Univ-Lyon 1, F69621 Villeurbanne, France, INRA, UMR 1235, F-69600 Oullins, France

* Corresponding author

Dr. E. VERICEL

INSERM UMR 870 / INSA-Lyon

RMND, IMBL, Bât Louis Pasteur

20 Ave. A. Einstein

69621 Villeurbanne Cedex

Tel : 33472438479

Fax : 33472438524

E-mail : evelyne.vericel@insa-lyon.fr 
Summary

Beneficial effects of docosahexaenoic acid (DHA) intake in the prevention of cardiovascular diseases are known, and platelets play a crucial role in cardiovascular complications. However, high doses of DHA may increase lipid peroxidation and induce deleterious effects, notably in platelets. This led us to investigate the effect of DHA on gene expression of some enzymes controlling redox status and prostanoid formation in human megakaryoblastic cells (MEG-01 cell line). MEG-01 cells were incubated in presence of DHA (10 and $100 \mu \mathrm{mol} / \mathrm{L})$ for $6 \mathrm{~h}$. DHA enrichment upregulated glutathione peroxidase- 1 and thromboxane synthase mRNA. DHA increased gene catalase expression and up-regulated PPAR $\beta / \delta$ and PPAR $\gamma$ mRNA in presence of high concentration of DHA. In conclusion, our results support an antioxidant mechanism of DHA. The effects of DHA on cellular redox status could, with others, provide an explanation for the beneficial influence of low consumption of DHA on cardiovascular events.

Key words : docosahexaenoic acid, gene expression, megakaryocyte, glutathione peroxidase, catalase, oxidative stress, antioxidant, thromboxane synthase, phospholipids 


\section{Introduction}

It is now well established that dietary marine $\mathrm{n}-3$ polyunsaturated fatty acids (PUFA), especially docosahexaenoic acid (DHA) can reduce morbidity and mortality from cardiovascular diseases [1,2]. However some studies failed to report a beneficial association between $n-3$ fatty acid consumption and cardio-vascular events $[3,4]$.

DHA is highly oxidizable owing to the presence of its six double bonds in the 22-carbon fatty acyl chain and the peroxidation process provides a variety of lipid peroxides, including malondialdehyde (MDA), which have been implicated in the aetiology of cardiovascular diseases [5]. In agreement with these observations, several studies have reported higher peroxidation index and oxidative stress in some dietary interventions with high doses of n-3 PUFA [6,7].

Because circulating blood platelets are known to play a crucial role in the regulation of haemostasis, thrombosis and the initiation of atherosclerosis [8,9], some studies have focused on the effects of n-3 PUFA on platelet function. Previously, we have shown that small intake of n-3 PUFA decreased oxidative stress in platelets from elderly people $[10,11]$. Thus, DHA can exert opposite activities and we have found these different effects on human blood platelet redox status depending on the dose [12].

The role of PUFA in the regulation of gene transcription has been well documented [13] and PUFA regulate the activity and/or abundance of at least four transcription factor families including peroxisome proliferator-activated receptors (PPARs). However, data concerning DHA effects on redox status genes are less numerous. As platelets are produced from megakaryocytes as cytoplasmic fragments without genomic DNA, platelets are thought to have no synthetic capacity for transcription of nuclear material. Thus, the regulation of gene expression must occur 
during megakaryocytopoiesis. To study DHA-induced regulation of gene expression, we have chosen the immortalized human megakaryoblastic cell line (MEG-01 cells) as a model of megakaryocytes [14].

The present study was undertaken to mainly investigate the effects of different concentrations of DHA on some enzymes controlling the redox status and prostanoid formation in a well established megakaryocyte cell model.

\section{Materials and methods}

\section{Materials}

All chemicals and reagents were purchased from Sigma-Aldrich (St. Quentin Fallavier, France), unless otherwise specified. All tissue culture reagents were obtained from Fisher Bioblock Scientific (Illkirch, France).

\section{Cell culture}

MEG-01 cells (American Type Culture Collection) were cultured in Iscove's Modified Dulbecco's Medium (IMDM) containing $10 \%$ fetal bovine serum at $37^{\circ} \mathrm{C}$ and in a $5 \%$ $\mathrm{CO}_{2}$ atmosphere.

\section{DHA supplementation}

Ethanolic DHA solutions or ethanol were dried and incubated overnight under nitrogen at $37^{\circ} \mathrm{C}$ with complete IMDM medium containing human albumin (fatty acid free). Cells were incubated with medium supplemented or not with 10 and $100 \mu \mathrm{M}$ DHA (molar ratio of albumin 0.1 and 1, respectively) for 6 hours. 
Reverse transcriptase and real-time PCR

Total RNA was isolated from MEG-01 cells using a previously described method with Trizol Reagent according to the manufacturer's protocol [15]. After quantification, $1 \mu \mathrm{g}$ of total RNA was reverse transcribed into cDNA in presence of $100 \mathrm{U}$ Superscipt II (Invitrogen, Eragny, France) using both random hexamers and oligo(dT). Real time PCR was performed with Fast Start DNA Master SYBR Green kit using a Light-Cycler. Primers sequences are available on request (evelyne.vericel@insa-lyon.fr). The results were normalized to hypoxanthine phosphoribosyltransferase 1 mRNA level. Data were analyzed using Light-Cycler software (Roche Diagnosis).

\section{Malondialdehyde (MDA) determination}

The overall lipid peroxidation was evaluated by measuring MDA according to the HPLC method of Therasse and Lemonnier [16] with fluorometric detection $(\lambda$ excitation $515 \mathrm{~nm}, \lambda$ emission $553 \mathrm{~nm}$ ).

Arachidonic acid cyclooxygenation in MEG-01 cells

The oxygenation of exogenous arachidonic acid (AA) through the cyclooxygenase pathway was determined by incubating $10 \mu \mathrm{M}\left[1-{ }^{14} \mathrm{C}\right] \mathrm{AA}$ with MEG01 cells for $5 \mathrm{~min}$ at $37^{\circ} \mathrm{C}$. After lipid extraction, the oxygenated end-products were separated by thin-layer chromatography (TLC), and quantified with a Berthold TLC linear analyzer (Berthold Technologies LB511, Germany) [17].

\section{Fatty acid composition of phospholipid}

After total lipid extraction, phospholipids were separated from neutral lipids by TLC and phospholipid classes were then resolved in a second step by the eluent system 
chloroform/methanol/methylamine $(60: 25: 5, \mathrm{v} / \mathrm{v} / \mathrm{v})$ [18]. The phospholipids were transmethylated [19] and the resulting fatty acid methyl esters and fatty aldehyde dimethyl acetals (DMA) were analyzed by gas-liquid chromatography (GC) using BPx70 SGE column $(60 \mathrm{~m} \times 0.25 \mathrm{~mm} \times 0.25 \mu \mathrm{m})$.

\section{Statistical analysis}

Statistical analysis of differences was carried out by analysis of variance (ANOVA) test using StatView (version 5.0). A $p$ value of less than 0.05 (Fisher's PLSD test) was considered significant.

\section{Results}

\section{Regulation of redox enzyme expressions in response to $D H A$}

The MEG-01 cell line was used to determine whether DHA altered the expression pattern of a number of key genes involved in oxidative stress, including antioxidant enzymes and enzymes known to produce reactive oxygen species (ROS) such as NADPH oxidase. The mRNA levels of glutathione peroxidase 1 (UniGene access number $\underline{\text { Hs.76686 }}$ GPx-1) significantly increased after 6-hour DHA incubation with 10 $\mu \mathrm{M}$ (1.5 fold) or $100 \mu \mathrm{M}$ (2.5 fold) DHA. The mRNA of GPx-4 ( significantly increased but only with the highest DHA concentration (Fig. 1). Copperzinc containing superoxide dismutase (Cu-Zn SOD, $\underline{\text { Hs.443914) }}$ mRNA expression was neither modified by DHA concentration compared to mRNA expression in control untreated cells (Fig. 1). Catalase ( $\underline{\text { Hs.502302 }}$ ) mRNA slightly but significantly increased above control levels in cells incubated with $100 \mu \mathrm{M}$ DHA. Finally, as shown 
in Figure 1, p22phox (ㅌs.513803) mRNA level expression was not significantly modified by DHA compared to mRNA expression in control cells.

Regulation of PGH synthase and Tx synthase expressions in response to DHA The enzyme prostaglandin endoperoxide H synthase (PGH synthase) catalyzes the conversion of AA to prostaglandin endoperoxide $\mathrm{H}_{2}\left(\mathrm{PGH}_{2}\right) . \mathrm{PGH}_{2}$ is further converted into prostaglandins (PGs) and mainly into thromboxane $A_{2}$, one of the most potent platelet aggregatory and vasoconstricting substances, by thromboxane synthase ( $\underline{\text { Hs.520757}}$, Tx synthase). The levels of PGH synthase-1 (‥ compared to mRNA levels in control cells (Fig. 2). Tx synthase mRNA increased with $10 \mu \mathrm{M}$ (1.4 fold) and $100 \mu \mathrm{M}$ (2.2 fold) DHA (Fig. 2).

Regulation of PPAR $\beta / \delta$ and PPAR yexpressions in response to DHA

As fatty acids, including DHA, are known as natural ligands of PPARs, mRNA levels of $\operatorname{PPAR} \beta / \delta(\underline{\text { Hs.696032}})$ and PPAR $\gamma(\underline{\text { Hs.162646}})$ were measured after incubation with DHA on MEG-01 cells. Both PPAR $\beta / \delta$ and PPAR $\gamma$ mRNA expressions were significantly increased with the highest DHA concentration compared to control cells : PPAR $\beta / \delta$ mRNA expression by $99 \%$ and PPAR $\gamma$ mRNA by $88 \%$ compared with control cells (Fig. 3).

\section{Effects of DHA on MEG-01 MDA levels}

In order to determine whether the incubations of MEG-01 cells with DHA affected the overall lipid peroxidation, basal levels of MDA were measured after 6 hour incubation in the presence or absence of DHA. As shown in Table 1, $10 \mu \mathrm{M}$ DHA did not induce any significant changes of MDA concentrations compared to control cells. Significant 
increase $(51 \%)$ of MDA was observed with the highest concentration of DHA compared to controls.

\section{Effect of DHA on arachidonic acid cyclooxygenation in MEG-01 cells}

The conversion of exogenous AA into its main cyclooxygenase products (thromboxane $\mathrm{B}_{2}, \mathrm{PGE}_{2}$ and $\mathrm{PGA}_{2} / \mathrm{B}_{2}$ ) was measured. The corresponding results, given in Figure 4 , indicate that the formation of PGs was not altered by DHA, but a significant decrease of $\mathrm{TxB}_{2}$ was observed in cells incubated with $100 \mu \mathrm{M}$ DHA (Fig. 4).

\section{Effect of DHA on fatty acid composition of phospholipids}

Incorporation and distribution of DHA within MEG-01 phospholipids were determined, especially in the most important ones regarding n-3 PUFA esterification, namely phosphatidylethanolamine (PE) and phosphatidylcholine (PC). Table 2 shows the fatty acid composition of MEG-01 cell PE ( $\%$ of main fatty acids are only reported). DHA percentage was 2.1 fold higher than controls in MEG-01 cells incubated with $10 \mu \mathrm{M}$ DHA. This percentage of DHA was more elevated in cells incubated with $100 \mu \mathrm{M}$ DHA (3.6 fold increase). We can notice a significant increase of eicosapentaenoic acid (EPA, 20:5n-3) with the highest tested concentration of DHA. A concomitant significant decrease of $18: 1 n-9$ and 20:4n-6 was found. Similar results were observed for the main fatty acids in PC with a significant higher enrichment of EPA and DHA than in PE from cells incubated with $10 \mu \mathrm{M}$ and $100 \mu \mathrm{M}$ DHA (Table 3)

\section{Discussion}

Evidence to explain the positive association between cardiovascular health and intake of n-3 PUFA in epidemiologic studies [20] has accumulated since Dyerberg and 
Bang [21] reported the decreased platelet function in Inuits. In the present study, we investigated the expression of glutathione peroxidases, catalase and superoxide dismutase in MEG-01 cells, a cell line known to express characteristic features of platelet precursor cells, in presence of DHA. Our results show that DHA failed to induce $\mathrm{Cu}-\mathrm{Zn}$ SOD expression but up-regulated GPx-1 gene expression in a dosedependent manner. Incubation with DHA led to similar results on GPx-4 mRNA, however to much lesser extent. These findings are in agreement with a previous study [22] showing a modest but significant increase of mRNA GPx-4 by DHA. To explain the up-regulation of GPx, several mechanisms can be considered. First, PUFA gene control involves PPAR dependent pathway [23], and DHA is a ligand of the all three PPAR subtypes. In agreement with these findings, we found an increase in both PPAR $\beta / \delta$ and $\gamma$ mRNA expression in presence of DHA mainly with a high concentration of the fatty acid. Second, GPx-1, one of the major detoxification enzymes, catalyzes the degradation of hydroperoxides to the corresponding alcohols [24]. GPx-4 has the important property of directly reducing lipid hydroperoxides in membranes. GPx-1 and GPx-4 are present in platelets $[25,26]$. These enzymes play a key role in the protection of cells from oxidative damage and also regulate the formation of eicosanoids, since their formation depends on the cell peroxide tone. Our results are consistent with those of Schonberg et al. [27] which found that GPx mRNA was increased in a human cancer line in response to DHA that induced lipid peroxidation. The up-regulations of GPx-1 and 4 expressions can play an important role in the protection against DHA-induced cytotoxicity. DHA-derived hydroperoxides, being substrates for these enzymes, are among the likely candidates for mediating cytotoxic effect. In addition, it is admitted that cellular stress leads to transcriptional activation of enzymes known to be involved in the primary antioxidant defence. In a recent study, it has also been shown that 
oxidative stress induced the expression of GPx but failed to induce the expression of $\mathrm{Cu}-\mathrm{Zn} \mathrm{SOD}[28]$ in agreement with our findings.

Because platelets are anucleated cells, PGH synthase- 1 content is a consequence of gene expression in megakaryocytes, so the effect of DHA on PGH-synthase-1 expression was investigated. DHA failed to induce PGH synthase-1 mRNA expression. Few and conflicting reports are available showing either inhibition [29] or enhancement [30] of PGH-synthase-1 by DHA. By contrast, our data are the first to show up-regulation of thromboxane synthase. This enzyme catalyzes the conversion of prostaglandin $\mathrm{H}_{2}$ to thromboxane $\mathrm{A}_{2}\left(\mathrm{TxA}_{2}\right)$, a potent vasoconstrictor and proaggregatory substance but also of prostaglandin $\mathrm{H}_{3}$ to thromboxane $\mathrm{A}_{3}$ from EPA which has considerably less activity than $\operatorname{TxA}_{2}$ [31]. This $\mathrm{TxA}_{3}$ could be synthesized even in presence of DHA since DHA can be retroconverted to EPA in many cells and our results show such a retroconversion in MEG-01 cells. Interestingly, the effect of DHA on thromboxane synthase was concentration-dependent. Moreover, the highest concentration of DHA induced an increased formation of MDA [12] and the oxidative stress induced by DHA might also up-regulate the expression of thromboxane synthase. Although DHA failed to affect PGH synthase-1 mRNA, it is known that DHA is a potent inhibitor of PGH synthase [32]. In agreement, cyclooxygenase activity, measured in presence of exogenous AA, was reduced after DHA treatment, and this resulted in a decreased thromboxane formation, despite the increased expression of thromboxane synthase.

Last, DHA is highly incorporated in platelet PC and PE [33] which reflects its endogenous distribution, and we found a similar pattern for megakaryocyte in PC and PE. This means that the alterations caused in megakaryocytes by DHA enrichment may be representative of those observed in platelets. 
In summary, our findings indicate that DHA up-regulates GPx-1 gene expression in a megakaryocyte cell line. Since the beneficial effects of DHA can no longer be doubted, numerous studies suggest several cellular mechanisms. In the present study, we cannot conclude whether the action on GPx expression was due to esterified DHA in phospholipids, unesterified DHA or its metabolites. Nevertheless this work supports an additional antioxidant mechanism of this fatty acid in a human megakaryocyte cell line. Such an antioxidant mechanism could, together with other effects, be an explanation for the beneficial influence of low consumption of n-3 PUFA in cardiovascular events.

\section{Acknowledgements}

This work was supported by INSERM. We thank Dr. F. Morlé for his helpful technical advice. N. Guillot is a recipient of doctoral fellowships from the Ministère de l’Enseignement Supérieur et de la Recherche.

\section{References}

[1] J. Dyerberg, H.O. Bang, E. Stoffersen, S. Moncada, and J.R. Vane, Eicosapentaenoic acid and prevention of thrombosis and atherosclerosis? Lancet 2 (1978) 117-9.

[2] P.M. Kris-Etherton, W.S. Harris, and L.J. Appel, Fish consumption, fish oil, omega3 fatty acids, and cardiovascular disease. Circulation 106 (2002) 2747-57.

[3] F.M. Sacks, P.H. Stone, C.M. Gibson, D.I. Silverman, B. Rosner, and R.C. Pasternak, Controlled trial of fish oil for regression of human coronary atherosclerosis. HARP Research Group. J Am Coll Cardiol 25 (1995) 1492-8.

[4] C.M. Albert, C.H. Hennekens, C.J. O'Donnell, U.A. Ajani, V.J. Carey, W.C. Willett, J.N. Ruskin, and J.E. Manson, Fish consumption and risk of sudden cardiac death. Jama 279 (1998) 23-8.

[5] K. Yagi, Lipid peroxides and human diseases. Chem Phys Lipids 45 (1987) 337-51. 
[6] J.E. Brown, and K.W. Wahle, Effect of fish-oil and vitamin E supplementation on lipid peroxidation and whole-blood aggregation in man. Clin Chim Acta 193 (1990) 147-56.

[7] J.P. Allard, R. Kurian, E. Aghdassi, R. Muggli, and D. Royall, Lipid peroxidation during n-3 fatty acid and vitamin E supplementation in humans. Lipids 32 (1997) 535-41.

[8] S. Massberg, K. Brand, S. Gruner, S. Page, E. Muller, I. Muller, W. Bergmeier, T. Richter, M. Lorenz, I. Konrad, B. Nieswandt, and M. Gawaz, A critical role of platelet adhesion in the initiation of atherosclerotic lesion formation. J Exp Med 196 (2002) 887-96.

[9] E. Vericel, C. Januel, M. Carreras, P. Moulin, and M. Lagarde, Diabetic Patients Without Vascular Complications Display Enhanced Basal Platelet Activation and Decreased Antioxidant Status. Diabetes 53 (2004) 1046-1051.

[10] M. Croset, E. Vericel, M. Rigaud, M. Hanss, P. Courpron, M. Dechavanne, and M. Lagarde, Functions and tocopherol content of blood platelets from elderly people after low intake of purified eicosapentaenoic acid. Thromb Res 57 (1990) $1-12$.

[11] E. Vericel, C. Calzada, P. Chapuy, and M. Lagarde, The influence of low intake of n-3 fatty acids on platelets in elderly people. Atherosclerosis 147 (1999) 187-92.

[12] E. Vericel, A. Polette, S. Bacot, C. Calzada, and M. Lagarde, Pro- and antioxidant activities of docosahexaenoic acid on human blood platelets. J Thromb Haemost 1 (2003) 566-72.

[13] D.B. Jump, Dietary polyunsaturated fatty acids and regulation of gene transcription. Curr Opin Lipidol 13 (2002) 155-64.

[14] M. Ogura, Y. Morishima, R. Ohno, Y. Kato, N. Hirabayashi, H. Nagura, and H. Saito, Establishment of a novel human megakaryoblastic leukemia cell line, MEG- 01, with positive Philadelphia chromosome. Blood 66 (1985) 1384-1392.

[15] P. Chomczynski, and N. Sacchi, Single-step method of RNA isolation by acid guanidinium thiocyanate-phenol-chloroform extraction. Anal Biochem 162 (1987) 156-9.

[16] J. Therasse, and F. Lemonnier, Determination of plasma lipoperoxides by highperformance liquid chromatography. J Chromatogr 413 (1987) 237-41. 
[17] D. Boukhchache, and M. Lagarde, Interactions between prostaglandin precursors during their oxygenation by human platelets. Biochim Biophys Acta 713 (1982) 386-92.

[18] N. Brossard, M. Croset, C. Pachiaudi, J.P. Riou, J.L. Tayot, and M. Lagarde, Retroconversion and metabolism of [13C]22:6n-3 in humans and rats after intake of a single dose of [13C]22:6n-3-triacylglycerols. Am J Clin Nutr 64 (1996) 577-86.

[19] D.E. Bowyer, W.M. Leat, A.N. Howard, and G.A. Gresham, The Determination of the Fatty Acid Composition of Serum Lipids Separated by Thin-Layer Chromatography; and a Comparison with Column Chromatography. Biochim Biophys Acta 70 (1963) 423-31.

[20] Dietary supplementation with n-3 polyunsaturated fatty acids and vitamin E after myocardial infarction: results of the GISSI-Prevenzione trial. Gruppo Italiano per lo Studio della Sopravvivenza nell'Infarto miocardico. Lancet 354 (1999) 447-55.

[21] J. Dyerberg, and H.O. Bang, Haemostatic function and platelet polyunsaturated fatty acids in Eskimos. Lancet 2 (1979) 433-5.

[22] A.A. Sneddon, H.C. Wu, A. Farquharson, I. Grant, J.R. Arthur, D. Rotondo, S.N. Choe, and K.W. Wahle, Regulation of selenoprotein GPx4 expression and activity in human endothelial cells by fatty acids, cytokines and antioxidants. Atherosclerosis 171 (2003) 57-65

[23] S.A. Kliewer, S.S. Sundseth, S.A. Jones, P.J. Brown, G.B. Wisely, C.S. Koble, P. Devchand, W. Wahli, T.M. Willson, J.M. Lenhard, and J.M. Lehmann, Fatty acids and eicosanoids regulate gene expression through direct interactions with peroxisome proliferator-activated receptors alpha and gamma. Proc Natl Acad Sci U S A 94 (1997) 4318-23.

[24] L. Flohe, Glutathione peroxidase. Basic Life Sci 49 (1988) 663-8

[25] R. Brigelius-Flohe, Tissue-specific functions of individual glutathione peroxidases. Free Radic Biol Med 27 (1999) 951-65

[26] C. Januel, F.Z. El Hentati, M. Carreras, J.R. Arthur, C. Calzada, M. Lagarde, and E. Vericel, Phospholipid-hydroperoxide glutathione peroxidase (GPx-4) localization in resting platelets, and compartmental change during platelet activation. Biochim Biophys Acta 1761 (2006) 1228-34. 
[27] S.A. Schonberg, P.K. Rudra, R. Noding, F. Skorpen, K.S. Bjerve, and H.E. Krokan, Evidence that changes in Se-glutathione peroxidase levels affect the sensitivity of human tumour cell lines to n-3 fatty acids. Carcinogenesis 18 (1997) 1897-904.

[28] S. Sharma, O. Dewald, J. Adrogue, R.L. Salazar, P. Razeghi, J.D. Crapo, R.P. Bowler, M.L. Entman, and H. Taegtmeyer, Induction of antioxidant gene expression in a mouse model of ischemic cardiomyopathy is dependent on reactive oxygen species. Free Radic Biol Med 40 (2006) 2223-31.

[29] F. Achard, M. Gilbert, C. Benistant, S. Ben Slama, D.L. DeWitt, W.L. Smith, and M. Lagarde, Eicosapentaenoic and docosahexaenoic acids reduce PGH synthase 1 expression in bovine aortic endothelial cells. Biochem Biophys Res Commun 241 (1997) 513-8.

[30] D. Sankaran, J. Lu, M.R. Ogborn, and H.M. Aukema, COX-2 expression in cystic kidneys is dependent on dietary n-3 fatty acid composition. J Nutr Biochem 18 (2007) 806-12.

[31] S. Fischer, and P.C. Weber, Thromboxane A3 (TXA3) is formed in human platelets after dietary eicosapentaenoic acid (C20:5 omega 3). Biochem Biophys Res Commun 116 (1983) 1091-9.

[32] E.J. Corey, C. Shih, and J.R. Cashman, Docosahexaenoic acid is a strong inhibitor of prostaglandin but not leukotriene biosynthesis. Proc Natl Acad Sci U S A 80 (1983) 3581-4

[33] M. Croset, Y. Bayon, and M. Lagarde, Incorporation and turnover of eicosapentaenoic and docosahexaenoic acids in human blood platelets in vitro. Biochem J 281 (Pt 2) (1992) 309-16. 


\section{Legends}

Fig. 1. Effect of DHA on the mRNA level of redox enzymes in MEG-01 cells. Cells were incubated in the absence (vehicle alone, human albumin) or presence of 10 and $100 \mu \mathrm{M}$ DHA for $6 \mathrm{~h}$ (corresponding to DHA/human albumin ratio 0.1 and 1 respectively). The mRNA levels were determined by quantitative real-time PCR. Data are expressed as fold change compared with the control and are means $\pm \mathrm{SEM}$, for four to five independent experiments; * indicates significant difference $v s$. control cells $\left({ }^{*} p<0.05\right) . \mathrm{Cu}-\mathrm{Zn} \mathrm{SOD}$ (copper-zinc containing superoxide dismutase 1), $C A T$ (catalase), GPx-1 (glutathione peroxidase 1), GPx-4 (glutathione peroxidase 4), $p 22^{\text {phox }}$ (component of NADH/NADPH oxidase).

Fig. 2. Effect of DHA on the mRNA level of arachidonic acid metabolism enzymes in MEG-01 cells. Cells were treated as described in the legend of Figure 1. Data are means $\pm \operatorname{SEM}(n=4$ to 5 ), and are expressed as fold change compared to untreated cells;

* indicates significant difference $v s$. control cells $\left({ }^{*} p<0.05\right)$. PGH synthase-1 (prostaglandin-endoperoxide synthase 1), Tx synthase (thromboxane A synthase 1).

Fig. 3. Effect of DHA on the mRNA level of peroxisome proliferator-activated receptors in MEG-01 cells. Cells were treated as described in the legend of Figure 1. Data are means $\pm \operatorname{SEM}(\mathrm{n}=4)$ and are expressed as fold change in mRNA levels compared to untreated cells; * indicates significant difference $v s$. control cells $\left({ }^{*} p<0.05\right) . P P A R \beta / \delta$ (peroxisome proliferator-activated receptor delta), PPAR $\gamma$ (peroxisome proliferator-activated receptor gamma). 
Fig. 4. Effect of DHA on cyclooxygenase activity in MEG-01 cells. Cells were treated as described in the legend of Fig. 1. Data are means $\pm \operatorname{SD}(n=3) ; *$ indicates significant difference $v$ s. control cells $\left({ }^{*} p<0.05\right) . T x B_{2}$ : thromboxane $\mathrm{B}_{2}, \ll \mathrm{PGE}_{2} »: \mathrm{PGE}_{2}$ and its metabolites $\mathrm{PGA}_{2} / \mathrm{PGB}_{2}$.

Table 1. Effect of DHA on MDA production in MEG-01 cells. Cells were cultured as described above. MDA production was determined by HPLC analysis. Data, expressed as $\mathrm{pmol} / \mu \mathrm{g}$ protein, are means $\pm \operatorname{SEM}(\mathrm{n}=4-5)$ experiments; $*$ indicates significant difference $v s$. control cells $\left({ }^{*} p<0.05\right)$.

Table 2. Effect of DHA on the fatty acid composition of phosphatidylethanolamine in MEG-01 cells. Cells were incubated as described above. Fatty acid composition was determined by GC analysis. Data, expressed as mole percent, are means \pm SEM of 4 experiments. Minor fatty acids are included for calculation but not tabulated; * indicates significant difference $v s$. control cells $\left({ }^{*} p<0.05\right)$. DMA: dimethyl acetals.

Table 3. Effect of DHA on the fatty acid composition of phosphatidylcholine in MEG-01 cells. Cells were incubated as described above. Fatty acid composition was determined by GC analysis. Data, expressed as mole percent, are means $\pm \mathrm{SEM}$ of 4 experiments. Minor fatty acids are included for calculation but not tabulated; * indicates significant difference $v s$. control cells $\left({ }^{*} p<0.05\right)$. 
Table 1. Effect of DHA on MDA production in MEG-01 cells.

\author{
MDA \\ (pmol/ $\mu \mathrm{g}$ protein)
}

Control

$7.81 \pm 0.44$
$10 \mu \mathrm{M}$ DHA

$8.08 \pm 0.26$
$100 \mu \mathrm{M}$ DHA

$11.83 \pm 1.19^{*}$ 
Table 2. Effect of DHA on the fatty acid composition of phosphatidylethanolamine in MEG-01 cells.

\begin{tabular}{|l|c|c|c|}
\hline $\begin{array}{c}\text { Major fatty acids } \\
(\text { mol\%) }\end{array}$ & control & $\mathbf{1 0} \boldsymbol{\mu M}$ DHA & $\mathbf{1 0 0} \boldsymbol{\mu M}$ DHA \\
\hline 16:0-DMA & $8.9 \pm 1.8$ & $8.7 \pm 1.9$ & $8.6 \pm 1.4$ \\
$18: 0-\mathrm{DMA}$ & $12.0 \pm 3.1$ & $11.4 \pm 2.9$ & $11.6 \pm 2.5$ \\
\hline $16: 0$ & $4.5 \pm 0.3$ & $4.3 \pm 0.3$ & $4.5 \pm 0.7$ \\
\hline $18: 0$ & $10.9 \pm 0.1$ & $10.5 \pm 0.7$ & $11.6 \pm 0.7$ \\
\hline $18: 1 \mathrm{n}-9$ & $31.8 \pm 1.5$ & $30.9 \pm 2.6$ & $27.4 \pm 0.8^{*}$ \\
\hline $18: 2 \mathrm{n}-6$ & $3.6 \pm 0.7$ & $3.9 \pm 1.2$ & $2.9 \pm 1.0$ \\
\hline $20: 4 \mathrm{n}-6$ & $6.5 \pm 0.6$ & $5.5 \pm 0.7$ & $5.2 \pm 0.1^{*}$ \\
\hline $20: 5 \mathrm{n}-3$ & $1.7 \pm 0.3$ & $1.6 \pm 0.4$ & $2.7 \pm 0.1^{*}$ \\
\hline $22: 5 \mathrm{n}-3$ & $2.5 \pm 0.2$ & $2.0 \pm 0.2$ & $1.9 \pm 0.1^{*}$ \\
\hline $22: 6 \mathrm{n}-3$ & $3.2 \pm 0.4$ & $6.8 \pm 1.1^{*}$ & $11.8 \pm 0.7^{*}$ \\
\hline
\end{tabular}


Table 3. Effect of DHA on the fatty acid composition of phosphatidylcholine in MEG-01 cells.

\begin{tabular}{|c|c|c|c|}
\hline $\begin{array}{l}\text { Major fatty acids } \\
(\mathrm{mol} \%)\end{array}$ & control & $10 \mu \mathrm{M}$ DHA & $100 \mu \mathrm{M}$ DHA \\
\hline $16: 0$ & $20.16 \pm 0.43$ & $21.03 \pm 1.27$ & $22.36 \pm 0.57$ \\
\hline 18:0 & $10.16 \pm 0.54$ & $10.24 \pm 0.31$ & $8.48 \pm 0.25^{*}$ \\
\hline $18: 1 n-9$ & $47.12 \pm 0.34$ & $46.74 \pm 0.53$ & $39.01 \pm 0.6^{*}$ \\
\hline $18: 2 n-6$ & $2.97 \pm 0.21$ & $2.57 \pm 0.17$ & $2.93 \pm 0.41$ \\
\hline $20: 4 n-6$ & $1.56 \pm 0.27$ & $1.53 \pm 0.43$ & $1.79 \pm 0.12$ \\
\hline $20: 5 n-3$ & $0.38 \pm 0.09$ & $0.43 \pm 0.15$ & $1.18 \pm 0.10^{*}$ \\
\hline $22: 5 n-3$ & $0.71 \pm 0.13$ & $0.64 \pm 0.22$ & $0.74 \pm 0.08$ \\
\hline $22: 6 n-3$ & $0.94 \pm 0.17$ & $2.32 \pm 0.74^{*}$ & $9.38 \pm 0.49^{*}$ \\
\hline
\end{tabular}




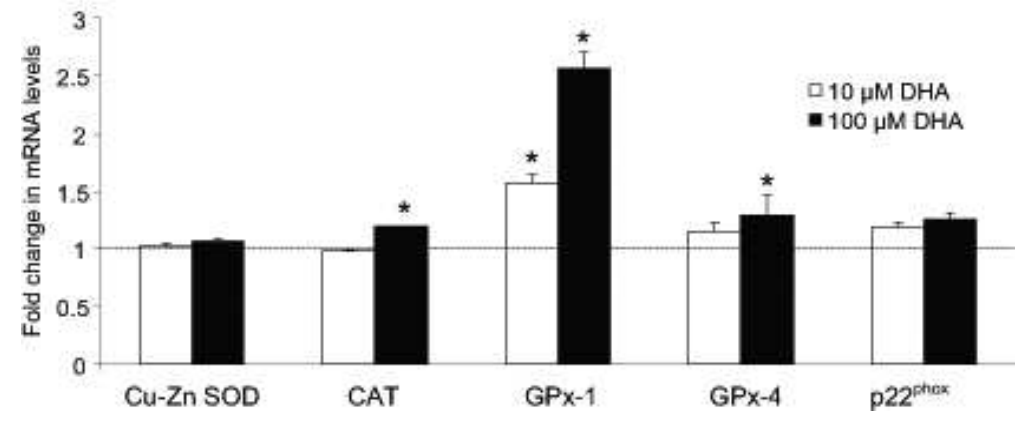


Figure 2

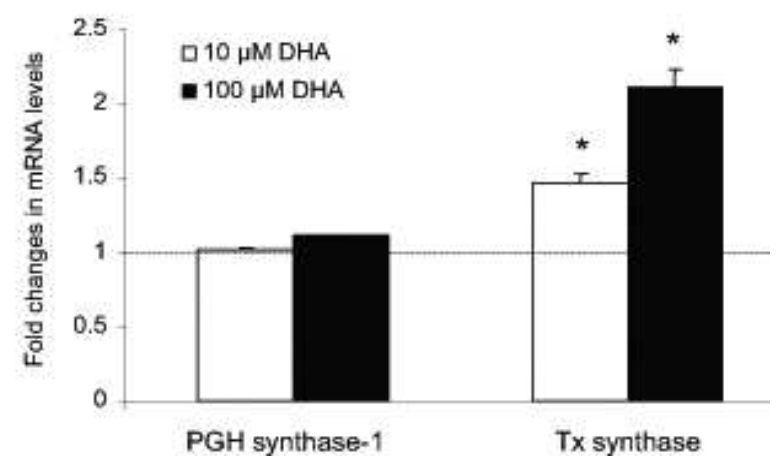


Figure 3

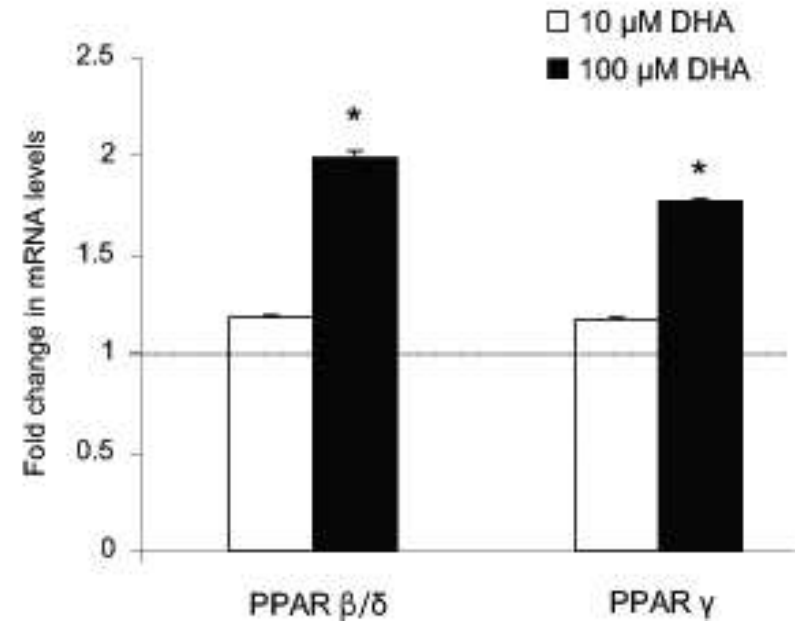


Figure 4

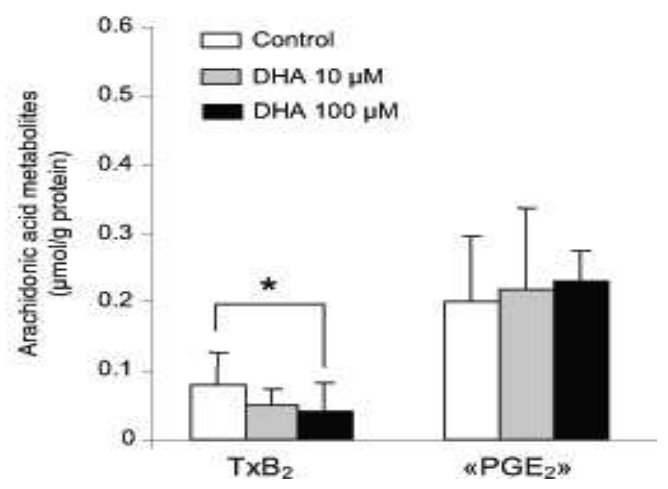

